\title{
A STUDY ON TESTICULAR CHARACTERISTICS OF RAM LAMBS OF ARSI BREED FED ON TWO MAIZE VARIETIES (QPM AND BH540)
}

\author{
Mehari Endale ${ }^{1}$, Mekonnen Hailemariam ${ }^{1, *}$ and Azage Tegegne ${ }^{2}$ \\ ${ }^{1}$ Faculty of Veterinary Medicine, Addis Ababa University, PO Box 34, Debre Zeit, \\ Ethiopia. E-mail: alemu57@yahoo.com \\ 2 International Livestock Research Institute (ILRI), PO Box 5689, Addis Ababa Ethiopia
}

\begin{abstract}
The effect of feeding two maize (Zea mays) varieties (Quality Protein Maize [QPM] and common maize [BH540]) on testicular characteristics of ram lambs was studied in the indigenous Arsi sheep breed. The two maize varieties were fed in whole plant silage (WPS), earless silage (ELS) and stover (s) forms for a period of 12 weeks. Variables measured during the feeding trial were scrotal circumference, testicular diameter and scrotal skin thickness in live ram lambs and testicular length, width, height and epididymis weight after slaughtering. There were no conclusive findings with regard to differences between the two maize varieties (QPM and BH540) in supporting growth rates of testicular traits, yet the offer types (WPS, ELS and S) did appear to have an effect. Ram lambs fed on whole plant silage had shown the highest $(\mathrm{P}<0.001)$ scrotal circumference $(28.1 \pm 0.3 \mathrm{~cm})$, scrotal circumference gain $(0.45 \pm 0.03 \mathrm{~mm} /$ head/day), testicular diameter $(5.77 \pm 0.09 \mathrm{~cm})$ and testicular diameter gain $(0.13 \pm 0.01$ $\mathrm{mm} /$ head/day) compared to the maize stover and earless silage fed groups. Testicular traits were positively and significantly correlated with each other $(\mathrm{r}=0.73$ to $0.95 ; \mathrm{P}<0.001)$. The results suggest that the plane of nutrition influences testicular size. Whole plant silage feeding provided improved testicular size. Therefore, maize whole plant silage feeding might be helpful to improve the productive and reproductive performance of ram lambs.
\end{abstract}

Key words/phrases: Ethiopia, maize, ram lambs, testicular traits

\section{INTRODUCTION}

Sheep are important meat producing animals in the Ethiopian highlands. However, their reproductive performance is, generally, poor and constitutes one of the major limiting factors for wider exploitation and profitability. The role of rams in influencing herd fertility and genetic progress has been recognized for a long time. Testicular size indicators (testicular weight, volume and diameter), scrotal circumference, and epididymal weight are significantly correlated with sperm production, output and quality (Rege et al., 2000; Al-Ghalban et al., 2004). Larger testes produce more spermatozoa, since, according to Gherardi et al. (1980), each gram of testis produces about $20 \times 10^{6}$ sperm cells per day, irrespective of size. On the other hand, several reports noted that testicular size is sensitive to nutritional changes (Mukassa-Mugerwa and Ezaz, 1992; Negussie Danaa et al., 2000).

Malnutrition and severe under nutrition are the major factors which retard growth and testicular development. In most parts of the tropics, including Ethiopia, natural pastures constitute the most important feed resource for sheep. They are, however, fibrous, deficient in energy and protein, and the supply of dry matter per hectare is highly variable (Ruth, 2002). More nutritious feed is, therefore, required for improved reproduction. Nutritious feed however, must be cheap and locally available.

Maize is the major staple food in Ethiopia and in many other African countries. In Ethiopia, it also constitutes the major food grain in total annual crop production and in area coverage with very low farm gate price (CSA, 1996; Mugos and Hoisington, 2001; SG-2000, 2001). Silage making from maize crop for dairy cattle feeding is practiced in large dairy farms. Maize stover is also a widely used basal diet for livestock in dry season (Tolera Abera, 2001). In recent years a new maize variety referred to as "Quality Protein Maize" (QPM) that has essential amino-acids (lysine and tryptophan) content higher than common maize is introduced to farmers. NRC (1988) reported that the biological value of QPM protein is about $90 \%$ of milk protein whereas that of common maize is only about $40 \%$. CIMMYT (2000) indicated that QPM could contribute towards improving protein deficiency both in human and animals. However, in Ethiopia, information on the nutritional effects

\footnotetext{
* Author to whom all correspondence should be addressed.
} 
of the QPM compared to the common maize variety on sheep reproductive performance is not available. Farmers using the QPM need to be better informed on the value and the biological interest of this cultivar.

Therefore, the aim of the present experiment was to obtain information on the effects of QPM compared to common maize variety (BH540) on testicular characteristics of ram lambs of the Arsi breed.

\section{MATERIALS AND METHODS}

The study was conducted at the International Livestock Research Institute (ILRI), Debre Zeit Research Station, located about $50 \mathrm{~km}$ southeast of Addis Ababa. The area has an altitude of $1850 \mathrm{~m}$ above sea level. According to the station's weather data recorded from 1992-2003, the area receives $815 \mathrm{~mm}$ mean annual rainfall in a bimodal pattern with short (March to May) and long (June to September) rainy seasons. Mean annual minimum and maximum temperatures are 11.7 and $26.4^{\circ} \mathrm{C}$, respectively.

\section{Experimental animals and diets}

Forty-nine ram lambs of 6 to 8 months of age and 18 to $21 \mathrm{~kg}$ body weight were purchased from the local market after close examination for physical and health conditions. The ram lambs were dewormed against internal and external parasites and vaccinated against sheep pox, peste des petits ruminants, and pasteurellosis.

The experimental diets were based on two maize (Zea mays) varieties namely quality protein maize (QPM) and improved common maize variety (BH540). QPM was produced by CIMMYT (International Maize and Wheat Improvement Centre) in Mexico in the mid-1980s. The two maize varieties (QPM and BH540) were offered in whole plant silage, earless silage and stover forms. Prior to the feeding trial, the ram lambs were adapted to the experimental diets for 8 weeks with a gradual increase to ad libitum feeding.

The ram lambs were then randomly put into seven groups (seven ram lambs per group). One group was randomly selected and slaughtered at the start to give base line information. The remaining six groups were kept in individual pens and randomly allotted to the experimental diets. The feeding trial had duration of 12 weeks.

Silage and stover on daily offer were at quantities that allow ad libitum feeding with a refusal of $25 \%$. Each ram lamb's daily allowance was computed based on the intake of previous three days, weighed by using an electrical balance (Sartonuis AS. Gottingon, Model QS 16000B, Germany) to the nearest $0.5 \mathrm{~g}$ and offered in six separate feedings of 2 hours intervals. Left-over of each animal was also weighed and recorded on daily basis.

A concentrate mixture supplement composed of wheat bran (59.8\%), "Noug" (Guizotia abyssinica) cake $(32.2 \%)$, bone meal $(6.5 \%)$ and salt $(1.5 \%)$ was formulated to provide $30 \%$ of the total dry matter and $22.5 \%$ of total protein intake. The chemical analysis of dietary treatments and the concentrate mixture (Table 1) was done following standard procedures (AOAC, 1995). The formulation of the concentrate mixture was based on the daily nutrients requirements estimation, nutrient contents of silage and stover and dry matter intake of the ram lambs. Twelve percent crude protein was set to meet the daily requirement from the total dry matter intake. The concentrate mixture was given at the rate of $227 \mathrm{~g}$ per animal per day. For the two stover groups (Groups 1 and 4), an extra 2.86g urea per animal and per day was added to balance the lower crude protein content of stover. The concentrate mixture was fed at 07:00h each morning. All the ram lambs had free access to water.

Table 1: Chemical composition ( $\mathrm{g} / \mathrm{kg} \mathrm{DM})$ of dietary treatments and concentrate mixture (AOAC, 1995).

\begin{tabular}{lccccccc}
\hline Feed & DM & OM & CP & NDF & ADF & ADL & ADF-ash \\
\hline QPM & & & & & & & \\
$\quad$ Stover & 917.1 & 913.1 & 42.3 & 737.1 & 455.7 & 56.8 & 33.7 \\
$\quad$ Whole plant silage & 280.6 & 920.2 & 75.8 & 635.9 & 377.4 & 36.8 & 41.0 \\
$\quad$ Earless silage & 272.4 & 895.8 & 59.7 & 648.0 & 421.0 & 51.8 & 60.0 \\
BH50 & & & & & & & \\
$\quad$ Stover & 915.2 & 904.8 & 50.4 & 775.3 & 493.7 & 66.0 & 41.7 \\
$\quad$ Whole plant silage & 239.1 & 918.8 & 74.3 & 619.9 & 380.7 & 38.7 & 43.5 \\
$\quad$ Earless silage & 242.0 & 895.4 & 54.3 & 679.4 & 444.3 & 55.2 & 59.1 \\
Concentrate mixture & 906.8 & 889.2 & 210.0 & 391.0 & 157.5 & 44.6 & 6.7 \\
\hline
\end{tabular}

Note: QPM : quality protein maize; BH540: common maize; DM: dry matter; OM: organic matter; CP: crude protein $(\mathrm{N} \times 6.25)$; NDF: neutral detergent fiber; ADF: acid detergent fiber; ADL: acid detergent lignin; Concentrate mixture contained 59.8\% wheat bran, 32.2\% Noug (Guizotia abyssinica) cake, $6.5 \%$ bone meal and $1.5 \%$ salt. 
The six dietary groups were:

Group 1 (QPM-S): consists of animals fed on Quality Protein Maize-stover, concentrate mixture and urea.

Group 2 (QPM-WPS): consisted of animals fed on Quality Protein Maize-whole plant silage and concentrate mixture.

Group 3 (QPM-ELS): consisted of animals fed on Quality Protein Maize-earless silage and concentrate mixture.

Group 4 (BH540-S): consisted of animals fed on common maize stover, concentrate mixture and urea.

Group 5 (BH540-WPS): consisted of animals fed on common maize whole plant silage and concentrate mixture.

Group 6 (BH540-ELS): consisted of animals fed on common maize earless silage and concentrate mixture.

\section{Parameters measured on ram lambs}

Scrotal measurements were taken fortnightly before morning feedings at the point of the greatest paired testes circumference, as described by Negussie Danaa et al. (2000). The testicular diameter was measured at the widest craniocaudal direction and scrotal skin thickness, at the base of the scrotum, between the two testes, using a Vernier Calliper (Tricle Brand, Model 0-150mm, Shanghai, China ).

\section{Parameters measured upon slaughtering}

All the ram lambs (42 ram lambs) were slaughtered at the end of the 12th week of feeding period. Their genital tracts were carefully removed upon dressing the carcasses. Then, testicular length, width and height were measured by means of a Vernier caliper (Tricle Brand, Model 0-150mm, Shanghai, China). Testicular length was measured along the vertical axis of the testicle that represents the distance between the top of the tail and the head of the epididymis. Testicular width was measured, in a medio-lateral direction, at the widest middle portion along the horizontal axis of the testis placed on the flat surface; height was measured at the same widest middle portion, along the horizontal axis of testis, but in a craniocaudal direction (at right angles to the width measurement). Testis volume was determined using the water displacement technique. Testis weights (right and left) were measured using an electrical balance (Mettler Toledo, Model PG5002-S, Switzerland). The epididymis (right and left) were separated from the testes and weighed using an electrical balance (Mettler Toledo, Model PG5002-S, Switzerland).

\section{Statistical analysis}

The data were analyzed using the General Linear Model (GLM) procedures of the statistical analysis system (SAS, 2000). The GLM procedure for analysis of variance and PORC CORR for correlation analysis were used.

The statistical model used for the variables on testicular traits was:

$$
\mathrm{Y}_{\mathrm{ijk}}=\mu+\mathrm{V}_{\mathrm{i}}+\mathrm{F}_{\mathrm{j}}+(\mathrm{VF})_{\mathrm{ij}}+\varepsilon_{\mathrm{ijk}}
$$

where

$$
\begin{aligned}
\mathrm{Y}_{\mathrm{ijk}}= & \text { each of the response variable } \\
\mu & =\text { the overall mean } \\
\mathrm{V}_{\mathrm{i}}= & \text { effect of maize variety } \\
\mathrm{F}_{\mathrm{j}}= & \text { effect of form on offer } \\
(\mathrm{VF})_{\mathrm{ij}}= & \text { the effect of interaction } \mathrm{V} * \mathrm{~F} \text { and, } \\
\varepsilon_{\mathrm{ijk}}= & \text { the random residual error assumed to be } \\
& \text { normally distributed }
\end{aligned}
$$

Contrast parameter test was used to make relevant comparison in statistical differences between treatment means. Initial scrotal circumference and initial testis diameter were used as a covariate in comparing treatment means. Correlation analysis was used to determine the association of testicular measurements with each other.

\section{RESULTS}

\section{Scrotal measurements}

Tables 2 and 3 show least squares means ( \pm S.E.) and coefficient of variation (CV) for scrotal circumference (SC), testis diameter (TD) and their corresponding daily gains (SCG and TDG) and final scrotal skin thickness (FSST).

The effects of the two maize varieties (QPM and BH540) on SC and TD did not show significant difference when similar offer types were compared. However, within each maize variety, sheep fed on WPS had significantly higher values (P $<0.01$ ) both for SC and TD than those on ELS and S 
(Tables 2 and 3). The difference between the later two (ELS and S), however, was not significant, although $S$ groups tended to have slightly higher values than ELS groups. The overall mean of SC and TD were $26.7 \pm 0.21 \mathrm{~cm}$ and $5.42 \pm 0.06 \mathrm{~cm}$, respectively.

Daily gains in SC and TD were computed from regression of the respective individual sheep values on weeks of measurements (Figs 1 and 2) from which the response of testicular traits of sheep on WPS, for the two maize varieties (QPM, $0.45 \pm 0.05 \mathrm{~cm}$ and $\mathrm{BH} 540,0.46 \pm 0.05 \mathrm{~cm})$, were higher than the rest $(\mathrm{P}<0.01)$. Among the dietary groups, sheep fed on QPM-S $(0.30 \pm 0.05)$ had higher gain rates than BH540-ELS $(0.13 \pm 0.05)(\mathrm{P}<0.05)$, whereas the latter was not different from BH540-s $(0.21 \pm 0.05)$ and QPM-ELS $(0.17 \pm 0.05)$. Daily gains from the three offer types were different to each other $(\mathrm{P}<0.001)$. The gain rate for SC was faster than that of TD. The corresponding values ranged between $0.13 \pm 0.05$ to $0.45 \pm 0.03 \mathrm{~mm} / \mathrm{head} /$ day for SCG and $0.05 \pm 0.01$ to $0.130 \pm 0.01 \mathrm{~mm} /$ head/day for TDG, respectively (Table 3).

Table 2. Least-square means ( \pm S.E.) for scrotal circumference, scrotal circumference gain, testis diameter, testis diameter gain and scrotal skin thickness of ram lams fed on two maize varieties a.

\begin{tabular}{|c|c|c|c|c|c|c|c|c|c|}
\hline \multirow{3}{*}{ Parameters ${ }^{b}$} & \multicolumn{6}{|c|}{ Maize variety $^{c}$} & \multirow{3}{*}{$\begin{array}{l}\text { Signif. } \\
\text { Level }\end{array}$} & \multirow{2}{*}{\multicolumn{2}{|c|}{ Over all }} \\
\hline & & QPM & & & BH540 & & & & \\
\hline & WPS & ES & S & WPS & ES & S & & Mean & $\mathrm{CV}$ \\
\hline $\mathrm{SC}(\mathrm{cm})$ & $28 \pm 0.45^{a}$ & $25.8 \pm 0.45^{\mathrm{b}}$ & $26.9 \pm 0.45^{\mathrm{ab}}$ & $28.2 \pm 0.42^{\mathrm{a}}$ & $25.5 \pm 0.45^{b}$ & $26 \pm 0.46^{b}$ & ** & $26.7 \pm 0.21$ & 5.1 \\
\hline $\operatorname{SCG}(\mathrm{mm} / \mathrm{d})$ & $0.45 \pm 0.05^{\mathrm{a}}$ & $0.17 \pm 0.05^{\mathrm{bc}}$ & $0.30 \pm 0.05^{\mathrm{ab}}$ & $0.46 \pm 0.05^{\mathrm{a}}$ & $0.13 \pm 0.05^{c}$ & $0.21 \pm 0.05^{\mathrm{bc}}$ & $* * *$ & $0.29 \pm 0.02$ & 44 \\
\hline $\mathrm{TD}(\mathrm{cm})$ & $5.75 \pm 0.12^{\mathrm{a}}$ & $5.25 \pm 0.13^{b}$ & $5.37 \pm 0.12^{b}$ & $5.78 \pm 0.11^{\mathrm{a}}$ & $5.06 \pm 0.12^{b}$ & $5.3 \pm 0.12^{\mathrm{b}}$ & $* *$ & $5.42 \pm 0.06$ & 7.2 \\
\hline TDG (mm/d) & $0.13 \pm 0.01^{\mathrm{a}}$ & $0.07 \pm 0.01^{b c}$ & $0.09 \pm 0.01^{\mathrm{b}}$ & $0.13 \pm 0.01^{\mathrm{a}}$ & $0.04 \pm 0.01^{c}$ & $0.08 \pm 0.01^{\mathrm{bc}}$ & $* * *$ & $0.09 \pm 0.01$ & 72 \\
\hline SST (cm) & $0.69 \pm 0.03^{a}$ & $0.64 \pm 0.03^{a}$ & $0.66 \pm 0.03^{a}$ & $0.61 \pm 0.03^{a}$ & $0.60 \pm 0.03^{a}$ & $0.64 \pm 0.03^{a}$ & NS & $0.64 \pm 0.01$ & 10.1 \\
\hline
\end{tabular}

Note a Means within the same row with different letters are significantly different from each other $(\mathrm{P}<0.05)$;

b SC: scrotal circumference; SCG: scrotal circumference gain; TD: testis diameter; TDG: testis diameter gain; SST: scrotal skin thickness;

' QPM: quality protein maize; BH540: common maize; WPS: whole plant silage; ELS: earless silage; S: stover; ${ }^{* *} \mathrm{P}<0.01 ;{ }^{* * *} \mathrm{P}<0.001 ; \mathrm{NS}$ : non-significant.

Table 3. Least-square means ( \pm S.E.) for scrotal circumference, scrotal circumference gain, testis diameter, testis diameter gain and scrotal skin thickness of ram lams fed on maize whole plant silage, earless silage and stover a.

\begin{tabular}{|c|c|c|c|c|c|c|c|}
\hline \multirow{3}{*}{ Parameters ${ }^{b}$} & \multicolumn{6}{|c|}{ Offer type ${ }^{\mathrm{C}}$} & \multirow{3}{*}{$\begin{array}{c}\text { Significance } \\
\text { level }\end{array}$} \\
\hline & \multicolumn{2}{|c|}{ WPS } & \multicolumn{2}{|c|}{ ES } & \multicolumn{2}{|c|}{$\mathrm{S}$} & \\
\hline & Mean ( \pm S.E.) & $\mathrm{CV}$ & Mean ( \pm S.E.) & $\mathrm{CV}$ & Mean ( \pm S.E.) & $\mathrm{CV}$ & \\
\hline $\mathrm{SC}(\mathrm{cm})$ & $28.1 \pm 0.3^{a}$ & 4 & $25.6 \pm 0.32^{b}$ & 4.7 & $26.5 \pm 0.32^{\mathrm{b}}$ & 4.5 & $* *$ \\
\hline $\operatorname{SCG}(\mathrm{mm} / \mathrm{d})$ & $0.45 \pm 0.03^{a}$ & 24.9 & $0.15 \pm 0.04^{\mathrm{c}}$ & 99.8 & $0.26 \pm 0.04^{b}$ & 57.6 & $* * *$ \\
\hline $\mathrm{TD}(\mathrm{cm})$ & $5.77 \pm 0.09 a$ & 5.8 & $5.16 \pm 0.09 b$ & 6.5 & $5.34 \pm 0.09 \mathrm{~b}$ & 6.3 & $* * *$ \\
\hline $\operatorname{TDG}(\mathrm{mm} / \mathrm{d})$ & $0.13 \pm 0.01^{\mathrm{a}}$ & 28.8 & $0.05 \pm 0.01^{b}$ & 77.6 & $0.08 \pm 0.01^{b}$ & 50.2 & $* * *$ \\
\hline SST $(\mathrm{cm})$ & $0.65 \pm 0.02 a$ & 8.1 & $0.62 \pm 0.02 a$ & 8.5 & $0.65 \pm 0.02 a$ & 8.1 & NS \\
\hline
\end{tabular}

Note: $\quad$ a Least-square means within the same row with different letters are significantly different from each other (P < 0.05);

b SC: scrotal circumference; SCG: scrotal circumference gain; TD: testis diameter; TDG: testis diameter gain; SST: scrotal skin thickness;

c WPS: whole plant silage; ELS: earless silage; S: stover; CV: coefficient of variation;

**: $\mathrm{P}<0.01 ;{ }^{* * *}$ : $<0.001 ;$ NS: non-significant. 


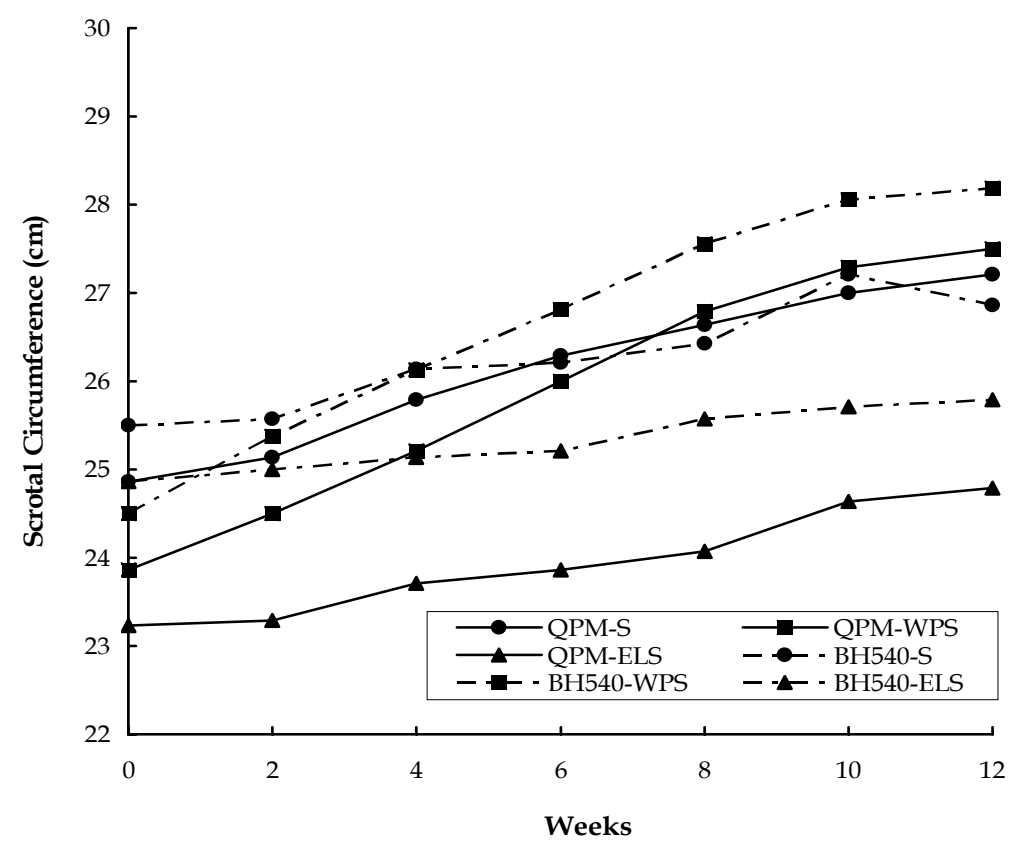

Fig. 1. Changes in scrotal circumference of Arsi ram-lambs fed on maize silage/stover.

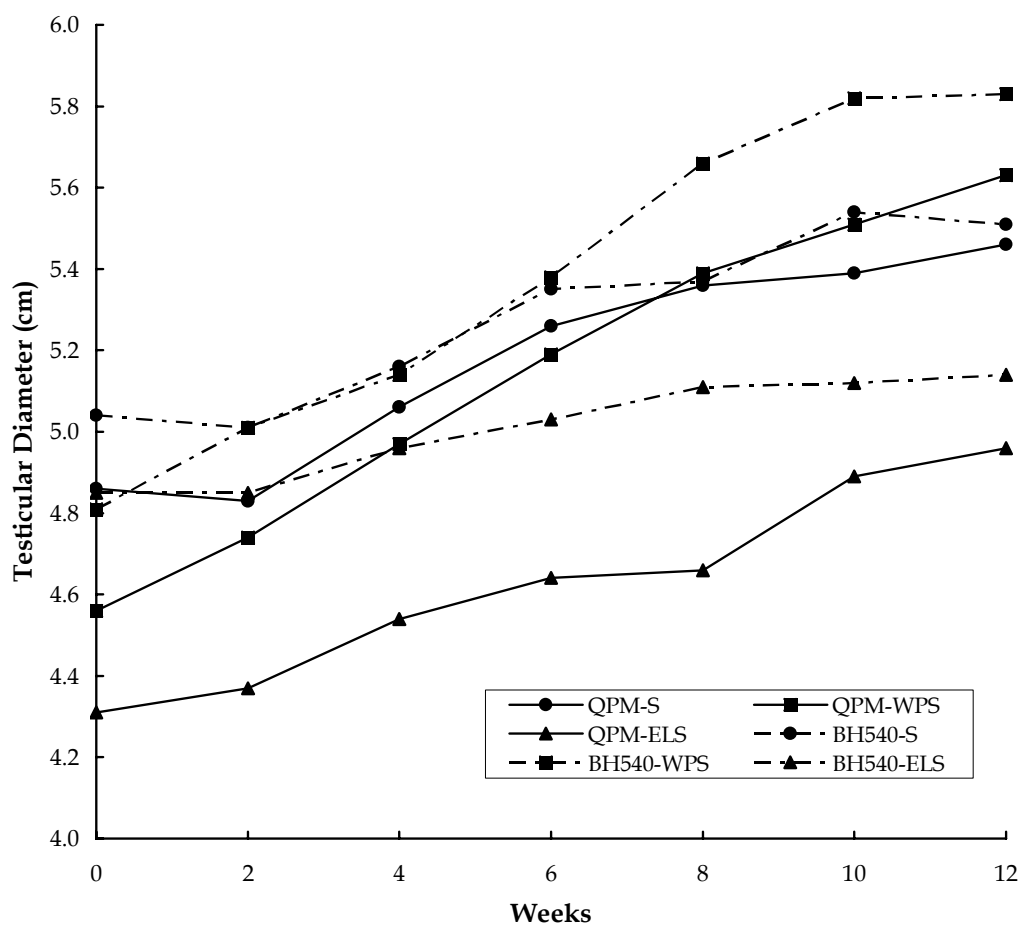

Fig. 2. Changes in testis diameter of Arsi ram lambs fed on maize silage or stover.

\section{Testicular traits of dressed carcasses}

Data on testicular characteristics measured at slaughter are presented in Tables 4 and 5. The values for all dietary treatment groups were higher than the initial slaughter group. Comparison between the two maize varieties (QPM and BH540) showed slightly higher values for BH540 fed groups in all measured parameters. Among the three forms of offer (WPS, ELS and S) of each maize variety (QPM or BH540), WPS tended to support the highest values in most of the measured testicular traits (testicular width, height, length, weight and volume) and epididymal weight $(\mathrm{P}<0.05)$ (Tables 4 and 5). In all the measured testicular traits, sheep fed on ELS exhibited consistently the lowest values. 
Table 4. Least-square means ( \pm S.E.) for testis weight, volume, length, width and height, and epididymis weight of ram lams fed on two maize varieties a.

\begin{tabular}{|c|c|c|c|c|c|c|c|c|}
\hline \multirow{3}{*}{ Parameters ${ }^{b}$} & \multirow{3}{*}{$\begin{array}{c}\text { Initial } \\
\text { slaughter } \\
\text { mean }\end{array}$} & \multicolumn{6}{|c|}{ Maize variety $^{c}$} & \multirow{3}{*}{$\begin{array}{l}\text { Signif } \\
\text { Level }\end{array}$} \\
\hline & & & QPM & & & BH540 & & \\
\hline & & WPS & ES & S & WPS & ES & $S$ & \\
\hline Testis weight $(\mathrm{g})$ & $183 \pm 12.1$ & $266 \pm 19.7^{a b}$ & $213 \pm 19.7^{b}$ & $242 \pm 21.2^{\mathrm{ab}}$ & $297 \pm 18.4^{a}$ & $232 \pm 19.7^{\mathrm{ab}}$ & $265 \pm 19.7 \mathrm{ab}$ & * \\
\hline Testis volume (ml) & $175 \pm 11.6$ & $263 \pm 20.2^{\mathrm{ab}}$ & $206 \pm 20.2^{b}$ & $233 \pm 21.9 \mathrm{ab}$ & $293 \pm 18.9 a$ & $229 \pm 20.3^{\mathrm{ab}}$ & $263 \pm 20.2^{\mathrm{ab}}$ & * \\
\hline Testis length (cm) & $7.3 \pm 0.19$ & $11.5 \pm 0.27^{\mathrm{a}}$ & $10.3 \pm 0.27 \mathrm{~b}$ & $11.1 \pm 0.29 \mathrm{ab}$ & $11.7 \pm 0.25 a$ & $10.6 \pm 0.29 \mathrm{ab}$ & $11.5 \pm 0.27 \mathrm{a}$ & * \\
\hline Testis Width (cm) & $5.3 \pm 0.13$ & $6.0 \pm 0.18^{a}$ & $5.7 \pm 0.18^{a}$ & $5.6 \pm 0.2^{\mathrm{a}}$ & $6.1 \pm 00.17 a$ & $5.7 \pm^{\mathrm{a}}$ & $6.0 \pm 0.18^{a}$ & NS \\
\hline Testis height (cm) & $4.6 \pm 0.14$ & $5.4 \pm^{\mathrm{a}}$ & $4.9 \pm 0.19 \mathrm{a}$ & $4.8 \pm 0.21^{\mathrm{a}}$ & $5.4 \pm 0.18 a$ & $4.9 \pm 0.21^{\mathrm{a}}$ & $5.3 \pm 0.19 a$ & NS \\
\hline Epididymis weight (g) & $29.6 \pm 1.56$ & $39.0 \pm 1.9 \mathrm{ab}$ & $31.6 \pm 1.96^{b}$ & $35.7 \pm 2.12^{\mathrm{ab}}$ & $41.2 \pm 1.83 a$ & $34.0 \pm 1.96^{\mathrm{b}}$ & $38.1 \pm 1.96^{\mathrm{ab}}$ & * \\
\hline
\end{tabular}

Note $\quad$ a Means within the same row with different letters are significantly different from each other $(\mathrm{P}<0.05)$.

${ }^{b}$ QPM: quality protein maize; BH540: common maize; WPS: whole plant silage; ELS: earless silage; S: stover

*: P < 0.05; NS: non-significant.

Table 5. Least-square means ( \pm S.E.) for testis weight, volume, length, width and height, and epididymis weight of ram lams fed on maize whole plant silage, earless silage and stover a.

\begin{tabular}{|c|c|c|c|c|c|c|}
\hline \multirow[b]{2}{*}{ Parameters ${ }^{b}$} & \multicolumn{3}{|c|}{ Offer type ${ }^{b}$} & \multirow{2}{*}{$\begin{array}{c}\text { Significance } \\
\text { level }\end{array}$} & \multicolumn{2}{|c|}{ Over all } \\
\hline & $\begin{array}{c}\text { WPS } \\
\text { Mean ( } \pm \text { S.E. })\end{array}$ & $\begin{array}{c}\text { ES } \\
\text { Mean ( } \pm \text { S.E. })\end{array}$ & $\begin{array}{c}\mathrm{S} \\
\text { Mean }\end{array}$ & & Mean & $\mathrm{CV}$ \\
\hline Testis weight $(\mathrm{g})$ & $286 \pm 13.5^{\mathrm{a}}$ & $223 \pm 13.9^{\mathrm{b}}$ & $254 \pm 14.5^{\mathrm{ab}}$ & * & $254 \pm 8.7$ & 22.2 \\
\hline Testis volume (ml) & $283 \pm 13.9^{a}$ & $217 \pm 14.9^{b}$ & $248 \pm 14.9^{\mathrm{ab}}$ & * & $249 \pm 8.9$ & 23.2 \\
\hline Testis length (cm) & $11.6 \pm 0.2^{\mathrm{a}}$ & $10.5 \pm 0.2^{b}$ & $11.3 \pm 0.2^{\mathrm{ab}}$ & $*$ & $11.2 \pm 0.13$ & 7.6 \\
\hline Testis Width (cm) & $6.1 \pm 0.13^{a}$ & $5.7 \pm 0.13^{a}$ & $5.8 \pm 0.13^{\mathrm{a}}$ & NS & $5.9 \pm$ & 8.8 \\
\hline Testis height (cm) & $5.4 \pm 0.13^{a}$ & $4.9 \pm 0.14^{\mathrm{a}}$ & $5.1 \pm 0.14^{\mathrm{a}}$ & NS & $5.1 \pm 0.08$ & 10.1 \\
\hline Epididymis weight (g) & $40.1 \pm 1.34^{a}$ & $32.8 \pm 1.39^{\mathrm{b}}$ & $36.9 \pm 1.44^{\mathrm{ab}}$ & $*$ & $36.7 \pm 0.96$ & 17 \\
\hline
\end{tabular}

Note $\quad$ a Means within the same row with different letters are significantly different from each other $(\mathrm{P}<0.05)$;

${ }^{\mathrm{b}}$ WPS: whole plant silage; ELS: earless silage; S: stover;

*: P < 0.05; NS: non-significat.

Strong positive correlations (Table 6) were obtained between SC, TD, TW, TV and EW $(\mathrm{r}=0.56$ to 0.95, $P<0.001$ ). SC and TD (testicular traits measured on live animals) were found to be strongly and positively associated with TW and TV ( $\mathrm{r}$ were comprised between 0.73 and $0.82, \mathrm{P}<0.001$ ) and to a lesser extent with EW $(r=0.63$ and 0.53 , respectively, $P<0.001$ ) (Table 6 ).

Table 6. Correlation coefficients between and among final body weight and testicular traits: Arsi Breed ram lambs, Ethiopia.

\begin{tabular}{|c|c|c|c|c|}
\hline & SC & TD & TW & TV \\
\hline SC & & $0.94^{* * *}$ & $0.82^{* * *}$ & $0.76^{\star * *}$ \\
\hline $\mathrm{TD}$ & & & $0.79 * * *$ & $0.73^{* * *}$ \\
\hline TW & & & & $0.95^{\star * *}$ \\
\hline
\end{tabular}

\section{DISCUSSION}

There were no conclusive findings with regard to differences between the two maize varieties (QPM and BH540) in supporting growth rates of testicular traits, yet the offer types (WPS, ELS and S) did appear to have an effect. The ram lambs fed on WPS performed better than the other two groups (ELS and $S$ fed groups). Moreover, the testicular traits in WPS fed groups had less CV than that of ELS or S fed groups, indicating less variability in testicular traits in WPS fed groups. Earless silage exhibited consistently lower values in all the measured testicular traits, and thus should not constitute the preferred form of use. There was no previous report on the QPM and BH540 maize feeding effects in indigenous breeds to compare the results of the present study.

The SC of 28 to $28.2 \mathrm{~cm}$ for WPS fed groups obtained in the present study is comparable to the reports of Negussie Danaa et al. (2000) for Ethiopian highland sheep fed with Leucaena leucocephala leaf hay and concentrate supplement $(26.2-28.6 \mathrm{~cm})$ and Al-Ghalban et al. (2004) for yearling Damascus bucks $(27.7 \mathrm{~cm})$, but much higher than the findings of Toe et al. (2000) who reported 23.2 and $23.5 \mathrm{~cm}$, respectively, for Menz and Horro breed ram lambs of 12 months age. The 
latter worked on ram lambs that grazed on paddocks in a rotational grazing system with ad libitum access to natural grass hay at night. Considering that both Menze and Horro are Ethiopian indigenous sheep breeds, the higher values in SC obtained in the present study might be, at least partly, due to the improved plane of nutrition. On the other hand, Zamiri and Khodaei (2005) who worked on mature (3-4 years old) Iranian fat tailed sheep, reported higher values $(35-36.75 \mathrm{~cm})$.

Progressive increases of SC and TD values over the experimental period were in agreement with other works (Elmaz et al.,2007). The SC growth rates of 0.13 to $0.45 \mathrm{~mm} /$ head/day obtained in the present study is, however, much higher than the reports of Kaitho et al. (1997) for Ethiopian highland sheep and goats $(0.08$ to 0.19 $\mathrm{mm} /$ head/day) showing that SC and TD responded to nutrition. In the present study, WPS provided improved testicular size. Therefore, WPS feeding might be helpful to improve the productive and reproductive performance of Arsi breed ram lambs.

The strong association among testicular traits obtained in the present study ( $(r=0.56$ to 0.95$)$ is in agreement with the findings of Negussie Danaa et al., (2000) ( $\mathrm{r}=0.7$ to 0.98). Several reports (Gherardi et al. 1980; Rege et al., 2000; Al-Ghalban et al., 2004) indicated the high correlation of SC, TD, TW, TV and EW with sperm production, output and quality. Gherardi et al. (1980) reported that each gram of testis produces about $20 \times 10^{6}$ sperm cells per day, irrespective of size. Therefore, SC and TD are a suitable trait as a selection criterion to improve reproductive performance. They are also a trait that can easily be measured in live animals.

The chronic underfeeding situation from which the ovine population is suffering is a common feature of the tropics. So the knowledge generated through this study will also have some relevance to the broader audience of workers in the region. Moreover, as the present study dealt with a pure indigenous breed, it could be considered as part of the global efforts aimed at preserving the genetics of indigenous breeds.

\section{ACKNOWLEDGEMENTS}

The authors wish to thank Sasakawa Global 2000 for financing the project and ILRI for providing all research facilities.

\section{REFERENCES}

1. Al-Ghalban, A.M., Tabbaa, M.J. and Kridli, R.T. (2004). Factors affecting semen characteristics and scrotal circumference in Damascus bucks. Small Rumin. Res. 53:141-149.

2. AOAC (1995). Official Methods of Analysis, $16^{\text {th }}$ edn. Association of Official Analytical Chemists (AOAC), AOAC, Inc., Arlington, Virginia, USA.

3. CSA (1996). Agricultural sample survey report on area production for major crops. Private peasant holdings. Central Statistical Authority (CSA). Statistical bulletin. 1(252). Addis Ababa, Ethiopia.

4. CIMMYT (2000). International Center for Maize and Wheat Improvement (CIMMYT) in 1999-2000. Science ans sustainance, Mexico D.F., pp. 6-7.

5. Elmaz, O., Cirit, U. and Demir, H. (2007). Relationship of testicular development with age, body weight, semen characteristics and testosterone in Kivircik ram lambs. South African J. Anim. Sci. 37(4):269-274.

6. Gherardi, P.B., Lindsay, D.R. and Oldham, C.M. (1980). Testicle size in rams and flock fertility. Proc. Aust. Soc. Anim. Prod. 13:48-50.

7. Kaitho, J.R., Azage Tegegne, Umunna, N.N., Nsahlai, I.V., Tamminga, S., Van Bruchem, J. and Arts, J.M. (1997). Effect of Leucaena and Sesbania supplementation on body growth and scrotal circumference of Ethiopian highland sheep and goats fed teff straw basal diet, Addis Ababa, Ethiopia.

8. Mugos, S. and Hoisington, D. (2001). Biotechnology for improvement of maize for resource poor farmer: The CIMMYT approach. In: Proceedings of the Second National Maize Workshop of Ethiopia, pp. 203-213. Nov. 12-16, 2001, Addis Ababa, Ethiopia.

9. Mukasa-Mugerwa, E. and Ezaz, Z. (1992). Relationship of testicular growth and size to age, body weight and onset of puberty in Menze ram lambs. Theriogenology 38:979-988.

10. NRC (1988). Quality Protein Maize (QPM). National Research Council (NRC). National Academy Press, Washington, D.C.

11. Negussie Danaa, Teshome Shenkoru and Azage Tegegne (2000). Growth rates and testicular characteristics of Ethiopian highland sheep offered chickpea haulm supplemented with incremental levels of Leucaena leucocephala leaf hay. Livestock Production Science 65:209-217.

12. Rege, J.E.D., Toe, F., Mukasa-Mugerwa, E., Tembely, S., Anindo, D., Baker, R.L. and Lahou-Kassi, A. (2000). Reproductive characteristics of Ethiopian highland sheep: Genetic parameters 
of testicular measurements. Small Rumin. Res. 37(3):173-187.

13. Ruth, M.G. (2002). Sheep, the Tropical Agriculturalist. CTA, MACMILLAN, Paris.

14. SAS (2000). SAS/STATTM User's Guide, Version 8. Cary SAS Institute Inc., Cary, North Carolina.

15. SG-2000 (2001). Impact of price fall of maize crop on the continued use of maize technology package: experience in 2001. Sasakawa Global2000 (SG-2000), Addis Ababa.

16. Toe, F., Rege, J.E.O., Mukasa-Mugerwa, E., Tembely, S., Anindo, D., Baker, R.L. and Lahlou-Kassi, A. (2000). Reproductive characteristics of Ethiopian highland sheep I. Genetic parameters of testicular measurements in ram lambs and relationship with age at puberty in ewe lambs. Small Rumin. Res. 36:227-240.

17. Tolera Abera (2001). Integrated feed and food production on smallholder mixed farms: Effect of early harvesting or variety on maize grain and stover yield and nutritive value of stover. In: Proceedings of the Second National Maize Workshop of Ethiopia, pp. 187-194. Nov. 12-16, 2001, Addis Ababa, Ethiopia.

18. Zamiri, M.J. and Khodaei, H.R. (2005). Seasonal thyroidal activity and reproductive characteristics of Iranian fat-tailed rams. Animal Reproduction Science 88:245-255. 